\title{
Species-Specific Relationship between Transpiration and Cadmium Translocation in Lettuce, Barley and Radish
}

\author{
Mst. Fardausi Akhter \\ Department of Biology, University of Western Ontario \\ London, ON, N6A 5B7, Canada \\ Tel: 1-519-661-2111(×86166) E-mail: makhter@uwo.ca \\ Sheila M. Macfie (Corresponding author) \\ Department of Biology, University of Western Ontario \\ London, ON, N6A 5B7, Canada \\ Tel: 1-519-661-2111(×86487) E-mail: smacfie@uwo.ca
}

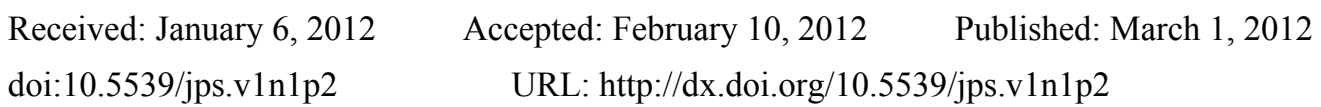

The research was financed by the Natural Sciences and Engineering Council of Canada Discovery Grant Program and the Metals in the Human Environment Strategic Network (a full list of sponsors is available at www.mithe-sn.org)

\begin{abstract}
Cadmium (Cd) may accumulate in plants to levels that are of concern in human diets. Our ability to predict the accumulation of $\mathrm{Cd}$ in plants is restricted by our poor understanding of the physiological processes that control $\mathrm{Cd}$ accumulation and translocation. A hydroponic experiment was carried out to test the hypothesis that the amount of Cd taken up and translocated to aboveground tissues is proportional to the volume of water transpired in lettuce (Lactuca sativa L.), barley (Hordeum vulgare L.) and radish (Raphanus sativus L.). Transpiration was measured as mass of water lost. Increased transpiration caused increased accumulation of Cd in plants; however, the proportion of total $\mathrm{Cd}$ translocated to the leaves ranged from $85 \%$ in lettuce to $66 \%$ in radish to only $21 \%$ in barley. Thus, factors controlling species-specific internal distribution of $\mathrm{Cd}$ are more important than transpiration in translocating $\mathrm{Cd}$ to aboveground tissues.
\end{abstract}

Keywords: Cadmium, Root: Shoot partitioning, Transpiration, Translocation

\section{Introduction}

Cadmium (Cd) is a non-essential element for almost all biota with the exception of Thalassiosira weissflogii (Grunow) G. Fryxell et Hasle, a marine diatom that uses $\mathrm{Cd}$ as a substitute for zinc ( $\mathrm{Zn}$ ) in the metalloenzyme carbonic anhydrase (Lane et al., 2005). The two main sources of $\mathrm{Cd}$ in soils are geological parent materials and inputs from anthropogenic sources (Nriagu \& Pacyna, 1988). Soils derived from Cd-rich parent materials can have concentrations up to $24 \mathrm{mg}$ total $\mathrm{Cd} \mathrm{kg}^{-1}$ (Alloway \& Steinnes, 1999). Anthropogenic sources include the application of manure and sewage sludge as well as certain industrial activities. In Canada, Cd-contaminated phosphorus (P) fertilizers are one of the major sources of Cd-contamination in agricultural systems and concentrations of $\mathrm{Cd}$ in $\mathrm{P}$ fertilizers could be as much as $300 \mathrm{mg} \mathrm{Cd} \mathrm{kg}^{-1}$ dry product (Grant \& Sheppard, 2008). The mean Cd concentration in the soil extract could be as high as $0.17 \mu \mathrm{g} \mathrm{l}^{-1}$, depending on the rate of P fertilizer application and the $\mathrm{Cd}$ concentration of the fertilizer (Lambert et al., 2007). Crops grown in contaminated soil may accumulate $\mathrm{Cd}$ in different plant parts, such as root, leaf, grain etc., and consumers may develop a number of Cd-related chronic diseases (Åkesson et al., 2006; Ogawa et al., 2004; Simmons et al., 2005). It is recommended to keep $\mathrm{Cd}$ concentrations below regulatory guidelines in vegetables, fruits, grains and other agricultural products to avoid metal toxicity (Canadian Food Inspection Agency [CFIA], 2011). Because the concentration of $\mathrm{Cd}$ in edible plant tissues is not always directly proportional to the concentration of $\mathrm{Cd}$ in the 
soil (Carbonell et al., 2011; Hejcman et al., 2009; Smolders et al., 2009; Wang et al., 2006), understanding the mechanisms of $\mathrm{Cd}$ accumulation and translocation in plants is important to ensuring food safety.

The ability of $\mathrm{Cd}$ to enter plants depends on a number of biotic and abiotic factors including plant species (Grant et al., 2008), microbial activity (Gao et al., 2010), soil pH (Mann \& Ritchie, 1993; Peijnenburg et al., 2000), soil organic matter (Murray et al., 2010), cation-exchange capacity (Bolan et al., 2003a, 2003b), presence of chelators, e.g., organic acids (Cieśliński et al., 1998), presence of competing or complexing ions (Gao et al., 2011), and amounts of total and plant-available Cd in the soil (Carbonell et al., 2011; Wang et al., 2006). Translocation of $\mathrm{Cd}$ within the plant depends on three major transport processes: passive and/or active uptake of Cd into the root (Cataldo et al., 1983; Zhao et al., 2002), xylem transport from the roots to the shoots (Uraguchi et al., 2009) and translocation to the seeds via phloem (Tanaka et al., 2007). Each of these processes is directly or indirectly correlated with water transport and transpiration rate. Since $\mathrm{Cd}$ is highly soluble in water, it is reasonable to expect a relationship between transpiration rate and $\mathrm{Cd}$ accumulation in plants.

The effect of $\mathrm{Cd}$ on transpiration of water from leaves has been studied extensively. At low concentrations, $\mathrm{Cd}$ increased the permeability of the leaf cuticle and increased transpiration in sugar beet (Beta vulgaris L.; Greger \& Johansson, 1992). At high concentrations, Cd induced stomatal closure and decreased leaf transpiration in mustard (Brassica juncea (L.) Czern; Haag-Kerwer et al., 1999), barley (Hordeum vulgare L.; Vassilev et al., 2002), and lettuce (Lactuca sativa L.; Mensah et al., 2008). However, the mechanism of Cd-induced stomatal closure is still poorly understood. Some studies reported increased production of abscisic acid (ABA) with increased Cd-exposure and suggested that ABA might regulate stomata closure in Cd-stressed conditions (Hsu \& Kao, 2003, 2005; Lòpez-Climent et al., 2011); however, in ABA-insensitive mutants of Arabidopsis thaliana (L.) Heynh Cd ${ }^{2+}$ affected guard cell regulation in an ABA-independent manner by entering the cytosol via $\mathrm{Ca}^{2+}$ channels (Perfus-Barbeoch et al., 2002).

While the effect of $\mathrm{Cd}$ on leaf transpiration has been well studied, little is known about the effect of transpiration on $\mathrm{Cd}$ accumulation and translocation in plants. In some cases, increased transpiration resulted in increased metal content. For example, when grown in artificial wastewater treated with different combinations of $\mathrm{Cd}$ and $\mathrm{Zn}$, young wheat (Triticum aestivum L.) seedlings accumulated more $\mathrm{Cd}$ and $\mathrm{Zn}$ under conditions with high vapor pressure deficit (VPD) of the atmosphere compared to low VPD (Salah \& Barrington, 2006). This finding is consistent with populations of American pokeweed (Phytolacca americana L.) that showed a positive correlation between $\mathrm{Cd}$ accumulation and transpiration when grown in nutrient solution (Liu et al., 2010). In contrast, no relationship was found between transpiration and Cd concentration in shoots of inbred lines of maize (Zea mays L.) grown in the field (Florijn \& Beusichem, 1993). The lack of consensus might be due to differences in species, duration of $\mathrm{Cd}$ exposure as well as the way transpiration was measured in the different studies. The species included hyperaccumulator weeds as well as low accumulator crop plants and the plants were either exposed to $\mathrm{Cd}$ in hydroponics for a short period of time or collected from contaminated fields. Transpiration measurement methods included amount of water lost per plant per day, amount of water lost per unit leaf area per second, and amount of water lost per unit dry weight of the shoot. The relationship between Cd content and these different measurements of transpiration may vary, especially if the plants being compared have markedly different leaf surface areas.

In this study, the hypothesis that the amount of $\mathrm{Cd}$ taken up and translocated to aboveground tissues is proportional to the total volume of water transpired in lettuce (Lactuca sativa L.), barley (Hordeum vulgare L.) and radish (Raphanus sativus $\mathrm{L}$.) grown in a non-toxic $\mathrm{Cd}$ concentration was tested. These three species were chosen because of their broad range of leaf areas, which were expected to correspond to a range in volumes of water transpired per plant, and because they represent a leaf, grain and root crop, respectively.

\section{Methods and Materials}

Chemicals, stock solution and reagents used were of analytical grade and all glassware was washed in soapy tap water, rinsed in tap water, soaked in $10 \%(\mathrm{v} / \mathrm{v})$ hydrochloric acid overnight, rinsed in RO (reverse osmosis) water and air-dried before use.

\subsection{Germination and growth conditions}

Seeds of each of three plant species, lettuce (L. sativa L. cv. Grand Rapids), barley (H. vulgare L. cv. CDC McGwire, hulless 2-row feed barley) and radish (R. sativus L. cv. Crimson Giant Champion), were germinated on moist (RO water) filter paper in Petri dishes in the dark for 24 hours. When the radicles were approximately $1 \mathrm{~cm}$ long, seedlings were transferred to pots $(15 \mathrm{~cm}$ diameter $)$ filled with rinsed sand supplemented with nutrient solution (Table 1) adjusted to $\mathrm{pH}$ 6.0. The seedlings were kept in a growth chamber set to $21^{\circ} \mathrm{C}$ with a 16 hour light and 8 hour dark cycle. The light intensity was $187 \pm 1.5 \mu \mathrm{mol} \cdot \mathrm{m}^{-2} \cdot \mathrm{s}^{-1}$ and relative humidity was set to $60 \%$. After 7 
days in sand culture, the roots were long enough to transfer the seedlings to hydroponics in $1.4 \mathrm{~L}$ glass jars. Different concentrations of $\mathrm{Cd}$ were added as $\mathrm{CdCl}_{2}$ to the nutrient solution and $\mathrm{pH}$ was set to 6.0 before seedlings were transferred to the jars. In a preliminary experiment, it was determined that concentrations of Cd above $5.0 \mu \mathrm{M}$ were toxic to lettuce and barley, and $1.0 \mu \mathrm{M} \mathrm{Cd}$ was toxic to radish. Therefore, the concentrations used in this experiment were $0,0.1,0.5,1.0$ and $2.0 \mu \mathrm{M} \mathrm{Cd}$ for lettuce and barley and $0,0.05,0.1,0.2$, and $0.5 \mu \mathrm{M} \mathrm{Cd}$ for radish. A total of three replicates were used for each treatment. In each jar (experimental replicate), one seedling was suspended in a folded $0.5 \times 1 \times 6 \mathrm{~cm}$ piece of foam and placed in a slot cut into a black plastic lid; this ensured that evaporative water loss was negligible. The sides of the jars were covered with black cloth to prevent algal growth. Each jar was hooked up to an aeration system and the plants were provided with fresh nutrient solution (including the corresponding Cd treatment) every second day.

\subsection{Transpiration and growth record}

The volume of nutrient solution lost per jar was determined by weighing the mass of each jar each time the nutrient solution was replaced, the daily transpirational water loss and the total volume of water lost were calculated from these values. Plant growth was recorded as crown diameter (lettuce) or shoot height (barley and radish) and measured every alternate day.

\subsection{Tissue harvest and biomass determination}

Plants were harvested 28 days after $\mathrm{Cd}$ treatments were applied. At harvest, roots and shoots were separated, rinsed in RO water and blotted dry. Fresh weight and total leaf area (as measured using a LI-3100 leaf area meter, LI-COR Inc., Lincoln, Nebraska, USA) for each plant were recorded. The roots were rinsed in RO water for 30 seconds then placed in $1 \mathrm{mM} \mathrm{CaCl} 2$ solution for 30 minutes followed by another 30 second wash in $\mathrm{RO}$ water (Taylor et al., 1998). This procedure desorbs Cd from the root surface by means of a cation exchange reaction between $\mathrm{Cd}^{2+}$ and $\mathrm{Ca}^{2+}$ and would remove Cd-containing nutrient solution from the surface of the roots. All tissues were oven dried $\left(60^{\circ} \mathrm{C}\right)$ until a constant weight was recorded.

\subsection{Cadmium content}

The concentration of $\mathrm{Cd}$ in roots and shoots was measured using a modified EPA test method SW-846 (United States Environmental Protection Agency [US EPA], 2005). The dried plant tissue was hand-chopped into fine pieces and ground using a mortar and pestle. A $0.1 \mathrm{~g}$ subsample was then placed in a $15 \mathrm{ml}$ test tube and covered using a glass marble to prevent evaporation while allowing pressure to be released. Standard reference material (SRM) from the National Institute of Standards and Technology (NIST 1573a, tomato leaves) and reagent blanks were used to assess accuracy, quality assurance and quality control. All the test tubes were placed in a rack and 1 $\mathrm{ml}$ pure nitric acid (OmniTrace ${ }^{\circledR}$, EM Science, USA) was added to each test tube to digest the organic matter. The samples were left overnight at room temperature. The following day, the test tube rack was placed in a shallow tray filled with sand and heated to $90-100^{\circ} \mathrm{C}$ on a hot plate until the vapors became transparent. Samples were allowed to cool to room temperature before being filtered (VWR, qualitative grade 413) into $50 \mathrm{ml}$ sterile disposable centrifuge tubes. Reverse osmosis water was used to rinse the test tubes and bring the volume to $50 \mathrm{ml}$. The samples were analyzed for Cd content by inductivity-coupled plasma atomic emission spectrometry (ICP-AES) using the following conditions: Perkin-Elmer Optima 3300 Dual view ICP-AES, RF generator power -1300 Watts, plasma flow rate $-15 \mathrm{~L} \mathrm{~min}^{-1}$, auxiliary flow rate $-0.5 \mathrm{~L} \mathrm{~min}^{-1}$, nebulizer flow rate $-0.8 \mathrm{~L} \mathrm{~min}^{-1}$, pump flow rate $1.0 \mathrm{~L} \mathrm{~min}^{-1}$, analyte line - $\mathrm{Cd} 226.507 \mathrm{~nm}$, plasma view - axial, with a detection limit of $0.001 \mathrm{ppm}$ for $\mathrm{Cd}$. The percentage recovery of $\mathrm{Cd}$ in the digested SRM was $84 \pm 5 \%$ and no $\mathrm{Cd}$ was detected in the reagent blanks.

\subsection{Statistical analysis}

SigmaPlot (version 11.0) was used for all statistical analysis and graphics. One-way ANOVA was used to detect treatment effects and Tukey's test was used to determine significant differences between treatment means $(P<0.05)$. Correlation and linear regression analyses were used to determine the relationship between transpiration rate and cadmium content.

\section{Results}

\subsection{Plant biomass}

The effects of $\mathrm{Cd}$ treatment on the dry biomass of each type of tissue are shown in Table 2. For lettuce, $\mathrm{Cd}$ exposure decreased both the shoot and root dry biomass and the leaves showed symptoms of Cd-induced stress (chlorosis, leaf rolling, etc.) at higher $\mathrm{Cd}$ doses. In the case of barley, $\mathrm{Cd}$ exposure slightly reduced shoot mass but had no effect on root mass (mid-panel in Table 2) and all seedlings looked healthy throughout the experimental period. Radish seedlings were sensitive to $\mathrm{Cd}$ and did not survive when grown in concentrations above $0.5 \mu \mathrm{M} \mathrm{Cd}$. 
Increasing concentrations of $\mathrm{Cd}$ did not consistently affect shoot mass of radish and had no effect on their root mass (bottom panel of Table 2).

\subsection{Plant transpiration}

The total volumes of water transpired and water loss per unit leaf area are shown in Table 3. Lettuce grown in the highest dose of $\mathrm{Cd}$ transpired $27 \%$ less total water than did plants grown in control solution but transpiration per unit leaf area was $75 \%$ higher for plants grown with $2.0 \mu \mathrm{M} \mathrm{Cd}$ relative to control plants. For both barley and radish, plants grown at the highest dose of $\mathrm{Cd}$ transpired $36 \%$ less water volume as compared to control plants, and $\mathrm{Cd}$ did not affect transpiration per unit leaf area. Among the three species studied, radish transpired the largest volumes of water and barley transpired the least.

\subsection{Cd content}

The effects of different concentrations of $\mathrm{Cd}$ in solution on plant $\mathrm{Cd}$ content are shown in Figure 1. As expected, concentrations of $\mathrm{Cd}$ in the tissues of all three species increased as the concentrations of $\mathrm{Cd}$ in the growth medium increased. Among species, total Cd concentrations were highest in barley (Figure 1c) and lowest in radish (Figure 1e). Within the species, shoot and root concentrations were equal under most experimental treatments for lettuce (Figure 1a) whereas $\mathrm{Cd}$ concentrations were higher in the roots compared to the shoots in barley (Figure 1c) and radish (Figure 1e). In radish, the lateral roots had much higher concentrations of $\mathrm{Cd}$ than did the tap roots (Figure 1e). When the total amount of $\mathrm{Cd}$ accumulated in each tissue was calculated (amount $=\mathrm{Cd}$ concentration $\mathrm{x}$ biomass) similar patterns emerged. The greatest amounts of $\mathrm{Cd}$ were measured in barley (Figure 1d) and the lowest amounts were measured in radish (Figure 1f). However, the three species responded differently in their ability to partition $\mathrm{Cd}$ among the different plant parts. Translocation of $\mathrm{Cd}$ from the roots to the shoots was measured by calculating shoot $\mathrm{Cd}$ as a percentage of total $\mathrm{Cd}$ (Table 4). In lettuce, $85 \%$ of the total $\mathrm{Cd}$ taken up by the plant was translocated to the leaves. In barley, most of the Cd taken up by the plant was retained in the roots and only $21 \%$ of the total $\mathrm{Cd}$ was translocated to the leaves. The pattern in radish was intermediate to the other two species; $66 \%$ of the total $\mathrm{Cd}$ was translocated to the leaves.

\subsection{Solution $C d$, transpiration and plant $C d$}

Regardless of the species, plants took up less than half of the total Cd supplied in the nutrient solution (Figure 2a) The total amount of $\mathrm{Cd}$ taken up by lettuce, barley and radish was approximately two to three times higher than the amount of $\mathrm{Cd}$ available through transpiration (Figure 2b), indicating involvement of membrane transport of $\mathrm{Cd}$ into these plants. The total amount of $\mathrm{Cd}$ in the plants was positively correlated with the amount of $\mathrm{Cd}$ available through transpiration (Figure $2 \mathrm{~b}$ ). The amounts of $\mathrm{Cd}$ translocated to the shoots of each species were also positively correlated with $\mathrm{Cd}$ available through transpiration (Figure 2c). However, the amounts of $\mathrm{Cd}$ in shoots of lettuce consistently exceeded the amounts predicted to be available through transpiration. Positive correlations were also found between the amount of $\mathrm{Cd}$ in the shoot and transpiration measured per unit leaf area in each species but the strongest correlation $\left(\mathrm{R}^{2}=0.67\right)$ was detected in lettuce (Figure 3). Although barley and radish transpired three times more water per unit leaf area compared to lettuce, the amounts of $\mathrm{Cd}$ in lettuce shoots were comparable to those in radish and up to three times higher than in barley.

\section{Discussion}

The main purpose of this study was to investigate the relationship between $\mathrm{Cd}$ content and total volume of water transpired in lettuce, barley and radish. While there was a positive correlation between $\mathrm{Cd}$ content and total volume of water transpired in all the three species, the intensity of the relationship was species-specific. We addressed the relationship using three approaches.

First, lettuce, barley and radish transpired different volumes of water throughout the study period and responded differently in terms of $\mathrm{Cd}$ accumulation. Radish transpired the largest volumes of water and accumulated the least amounts of $\mathrm{Cd}$ whereas barley transpired the least and accumulated the highest amounts of $\mathrm{Cd}$. When shoot $\mathrm{Cd}$ was plotted against the amounts of water transpired per unit leaf area, the strongest correlation was observed in lettuce.

Secondly, budgeting $\mathrm{Cd}$ amounts showed that all three species accumulated more $\mathrm{Cd}$ than was available through water uptake. So, it is confirmed that transpiration alone cannot explain plant $\mathrm{Cd}$ accumulation and it is likely that active uptake of $\mathrm{Cd}$ also took place in the studied species. A number of studies reported that $\mathrm{Cd}$ can enter the root through other divalent cation transporters, e.g. $\mathrm{Fe}^{2+}$ (Nakanishi et al., 2006) and $\mathrm{Ca}^{2+}$ (Zhao et al., 2002). Ueno et al. (2008) studied the uptake and translocation mechanism of $\mathrm{Cd}$ in Arabidopsis halleri (L.) and suggested that $\mathrm{Cd}$ entered the root through an energy-dependent process that is partly shared with $\mathrm{Zn}$ and/or Fe transport. Lombi et al. (2001) investigated the uptake and translocation characteristics of $\mathrm{Cd}$ and $\mathrm{Zn}$ for the 
hyperaccumulator Thlaspi caerulescens (L.) and raised the possibility of $\mathrm{Cd}^{2+}$ transporters in the root cell plasma membranes.

Thirdly, though less total $\mathrm{Cd}$ was measured in lettuce compared to barley and radish, lettuce shoots contained higher amounts of $\mathrm{Cd}$ than were measured in shoots of the other two species. This pattern could be explained if barley and radish had Cd-restriction mechanisms in the root that minimized translocation to the shoot. One of those mechanisms could be binding $\mathrm{Cd}$ with phytochelatins, sulphur-rich compounds that are synthesized upon $\mathrm{Cd}$ exposure in the cytoplasm and vacuole. Salt et al. (1995) reported Cd-S complexes in Indian mustard root and noted that most of the $\mathrm{Cd}$ taken up by Indian mustard was retained in the root. Moreover, different species may accumulate $\mathrm{Cd}$ in different compartments within the root. For example, Cd distribution in durum wheat (Triticum turgidum L. var. durum) was reported to be symplastic (Van der Vliet et al., 2007) whereas Cd distribution in bush beans (Phaseolus vulgaris L.) was reported as apoplastic (Hardiman \& Jacoby, 1984). It is possible that $\mathrm{Cd}$ distribution in monocots is mostly symplastic whereas in dicots $\mathrm{Cd}$ is sequestered in the apoplast; however, this idea needs confirmation. If the theory is true then $\mathrm{Cd}$ in lettuce may have been translocated to the shoot through apoplastic bypass whereas in barley $\mathrm{Cd}$ was immobilized in the symplast of the root.

Based on the above discussion we are convinced that plant $\mathrm{Cd}$ accumulation depends on multiple factors including bulk flow through transpiration, solution $\mathrm{Cd}$ concentration and a plant-specific factor. The relative contribution of each of these factors will determine how much $\mathrm{Cd}$ will move into the plant and subsequently be translocated to the aboveground part. This is consistent with the findings from several other studies conducted on potato, sugar beet, winter wheat (Ingwersen \& Streck, 2005) and radish (Kashem \& Singh, 2002) where it was shown that, rather than one single factor, $\mathrm{Cd}$ accumulation was driven by multiple factors including the ones mentioned above. In our study, regardless of species, plant $\mathrm{Cd}$ content increased with increased Cd concentration in the nutrient solution which is supported by the findings conducted on other species (Ingwersen \& Streck, 2005; Salah \& Barrington, 2006). The finding that all three plant species showed a positive correlation between shoot $\mathrm{Cd}$ and transpiration are in line with the observations from several other studies. Salah and Barrington (2006) studied wheat grown in a range of $0-0.5 \mathrm{mg} \mathrm{Cd} / \mathrm{L}$ and found that more $\mathrm{Cd}$ was taken up by the plants grown under high vapour pressure deficit (VPD) compared to the plants grown under low VPD and that increased Cd in the soil or nutrient solution increased plant Cd accumulation. Hardiman and Jacoby (1984) exposed 10 days old bush bean (Phaseolus vulgaris L.) in ${ }^{109} \mathrm{Cd}$ for 14 hours either at $68 \%$ or $97 \%$ relative humidity (RH) and found increased $\mathrm{Cd}$ content with increased transpiration. The mean $\mathrm{Cd}$ concentrations in the transpiration stream under both RH were similar and the authors suggested that increased Cd transport to the shoot under $68 \% \mathrm{RH}$ occurred in response to increased mass flow of solutes in the transpiration stream. Ingwerson \& Streck (2005) surveyed potato, winter wheat and sugar beet from contaminated sites and found increased $\mathrm{Cd}$ concentrations in the years with higher saturation deficit of the atmosphere and they suggested that about $66-82 \%$ of the relationship between $\mathrm{Cd}$ concentration in the crop and $\mathrm{Cd}$ concentration in the soil solution can be explained by the volume of water transpired. On the other hand, Florijn and Beusichem (1993) investigated different inbred lines of maize and found no correlation between $\mathrm{Cd}$ content of the shoots and transpiration.

Finally, until a plant-specific factor is added, $\mathrm{Cd}$ translocation cannot be explained completely. This plant-specific factor includes the ability of individual species to either exclude $\mathrm{Cd}$ in the rhizosphere through chelation with organic acid exudates from the plant in response to $\mathrm{Cd}$ exposure or pass $\mathrm{Cd}$ through the cell wall into the symplasm using cationic transporters for $\mathrm{Ca}^{2+}, \mathrm{Zn}^{2+}, \mathrm{Cu}^{2+}$ or $\mathrm{Fe}^{2+}$ present in the cell membrane (Lombi et al., 2001). Once Cd enters the root, it will either enter and bind with the chelators present in the symplast and restrict $\mathrm{Cd}$ movement to the aboveground part or be translocated directly to the aboveground parts through apoplastic bypass.

\section{Conclusions}

Approximately $85 \%$ of the $\mathrm{Cd}$ taken up by lettuce was accumulated in the leaves, whereas $80 \%$ of the $\mathrm{Cd}$ in barley was retained in the roots. In radish, $\mathrm{Cd}$ was more evenly distributed between aboveground and below ground tissues. $\mathrm{Cd}$ accumulation and translocation in lettuce, barley and radish depends on multiple factors including solution $\mathrm{Cd}$ concentration, transpiration, and a plant-specific internal compartmentation of $\mathrm{Cd}$ in the root. Preferential retention of $\mathrm{Cd}$ in the cell wall or sequestration in the vacuole might explain the observed differences in $\mathrm{Cd}$ distribution. So, understanding how and where $\mathrm{Cd}$ is stored in the roots is worthy of further investigation as this might enhance our understanding of $\mathrm{Cd}$ tolerance and differential translocation in lettuce, barley and radish. 


\section{References}

Åkesson, A., Bjellerup, P., Lundh, T., Lidfeldt, J., Nerbrand, C., \& Samsioe, G. (2006). Cadmium-induced effects on bone in a population-based study of women. Environmental Health Perspectives, 114, 830-834. http://dx.doi.org/10.1289/ehp.8763

Alloway, B. J., \& Steinnes, E. (1999). Anthropogenic addition of cadmium to soils. In M.J. McLaughlin \& B.R.Singh (Eds.). Cadmium in Soils and Plants (pp. 97-123). Dordrecht: Kluwer Academic Publishers, (Chapter $5)$.

Bolan, N. S., Adriano, D. C., Duraisamy, P., Mani, A., \& Arulmozhiselvan, K. (2003a). Immobilization and phytoavailability of cadmium in variable charge soils. I. Effect of phosphate addition. Plant and Soil, 250, 83-94. http://dx.doi.org/10.1023/A:1022826014841

Bolan, N. S., Adriano, D., Mani, P., \& Duraisamy, A. (2003b). Immobilization and phytoavailability of cadmium in variable charge soils. II. Effect of lime addition. Plant and Soil, 251, 187-198. http://dx.doi.org/10.1023/A:1023037706905

Canadian Food Inspection Agency. (2011). Canadian Food quality guidelines, Ottawa, Canada. [Online] Available: http://www.inspection.gc.ca/ (Dec 20, 2011)

Carbonell, G., Imperial, R. M., Torrijos, M., Delgado, M., \& Rodriguez, J. A. (2011). Effects of municipal solid waste compost and mineral fertilizer amendments on soil properties and heavy metals distribution in maize plants (Zea mays L.). Chemosphere, 85(10), 1614-1623. http://dx.doi.org/10.1016/j.chemosphere.2011.08.025

Cataldo, D. A., Garland, T. R., \& Wildung, R. E. (1983). Cadmium uptake kinetics in intact soybean plants. Plant Physiology, 73, 844-848. http://dx.doi.org/10.1104/pp.73.3.844

Cieśliński, G., Van Rees, K. C. J., Szmigielska, A. M., Krishnamurti, G. S., \& Huang, P. M. (1998). Low-molecular-weight organic acids in rhizosphere soils of durum wheat and their effect on cadmium bioaccumulation. Plant and Soil, 203, 109-117. http://dx.doi.org/10.1023/A:1004325817420

Florijn, P. J., \& Beusichem, M. L. V. (1993). Uptake and distribution of cadmium in maize inbred lines. Plant and Soil, 150, 25-32. http://dx.doi.org/10.1007/BF00779172

Gao, X., Akhter, F., Tenuta, M., Flaten, D. N., Gawalko, E. J., \& Grant, C. (2010). Mycorrhizal colonization and grain $\mathrm{Cd}$ concentration of field-grown durum wheat in response to tillage, preceding crop and phosphorus fertilization. Journal of the Science of Food and Agriculture, 90, 750-758. http://dx.doi.org/10.1002/jsfa.3878

Gao, X., Tenuta, M., Flaten, D. N., \& Grant, C. A. (2011). Cadmium concentration in flax colonized by mycorrhizal fungi depends on soil phosphorus and cadmium concentrations. Communications in Soil Science and Plant Analysis, 42, 1882-1897. http://dx.doi.org/10.1080/00103624.2011.587572

Grant, C. A., \& Sheppard, S. C. (2008). Fertilizer impacts on cadmium availability in agricultural soils and crops. Human and Ecological Risk Assessment: An International Journal, 14, 210-228. http://dx.doi.org/10.1080/10807030801934895

Grant, C. A., Clarke, J. M., Duguid, S., \& Chaney, R. L. (2008). Selection and breeding of plant cultivars to minimize cadmium accumulation. Science of the Total Environment, 390, 301-310. http://dx.doi.org/10.1016/j.scitotenv.2007.10.038

Greger, M., \& Johansson, M. (1992). Cadmium effects on leaf transpiration of sugar beet (Beta vulgaris). Physiologia Plantarum, 86, 465-473. http://dx.doi.org/10.1111/j.1399-3054.1992.tb01345.x

Haag-Kerwer, A., Schafer, H. J., Heiss, S., Walter, C., \& Rausch, T. (1999). Cadmium exposure in Brassica juncea causes a decline in transpiration rate and leaf expansion without effect on photosynthesis. Journal of Experimental Botany, 50, 1827-1835. http://dx.doi.org/10.1093/jxb/50.341.1827

Hardiman, R. T., \& Jacoby, B. (1984). Absorption and translocation of Cd in bush beans (Phaseolus vulgaris). Physiologia Plantarum, 61, 670-674. http://dx.doi.org/10.1111/j.1399-3054.1984.tb05189.x

Hejcman, M., Szaková, J., Schellberg, J., Šrek, P., \& Tlustoš, P. (2009). The Rengen grassland experiment: soil contamination by trace elements after 65 years of $\mathrm{Ca}, \mathrm{N}, \mathrm{P}$ and $\mathrm{K}$ fertiliser application. Nutrient Cycling in Agroecosystems, 83, 39-50. http://dx.doi.org/10.1007/s10705-008-9197-8

Hsu, Y. T., \& Kao, C. H. (2003). Role of abscisic acid in cadmium tolerance of rice (Oryza sativa L.) seedlings. Plant, Cell and Environment, 26, 867-874. http://dx.doi.org/10.1046/j.1365-3040.2003.01018.x 
Hsu, Y. T., \& Kao, C. H. (2005). Abscisic acid accumulation and cadmium tolerance in rice seedlings. Physiologia Plantarum, 124, 71-80. http://dx.doi.org/10.1111/j.1399-3054.2005.00490.x

Ingwersen, J., \& Streck, T. (2005). A regional-scale study on the crop uptake of cadmium from sandy soils: measurement and modeling. Journal of Environmental Quality, 34, 1026-1035. http://dx.doi.org/10.2134/jeq2003.0238

Kashem, M. A., \& Singh, B. R. (2002). The effect of fertilizer additions on the solubility and plant-availability of $\mathrm{Cd}, \mathrm{Ni}$ and $\mathrm{Zn}$ in soil. Nutrient Cycling in Agroecosystems, 62, 287-296. http://dx.doi.org/10.1023/A:1021226201136

Lambert, R., Grant, C., \& Sauvé, S. (2007). Cadmium and zinc in soil solution extracts following the application of phosphate fertilizers. Science of the Total Environment, 378, 293-305. http://dx.doi.org/10.1016/j.scitotenv.2007.02.008

Lane, T. W., Saito, M. A., George, G. N., Pickering, I. J., Prince, R. C., \& Morell, F. M. M. (2005). A cadmium enzyme from a marine diatom. Nature, 435, 42. http://dx.doi.org/10.1038/435042a

Liu, X., Peng, K., Wang, A., Lian, C., \& Shen, Z. (2010). Cadmium accumulation and distribution in populations of Phytolacca americana L. and the role of transpiration. Chemosphere, 78, 1136-1141. http://dx.doi.org/10.1016/j.chemosphere.2009.12.030

Lombi, E., Zhao, F. J., McGrath, S. P., Young, S. D., \& Sacchi, G. A. (2001). Physiological evidence for a high-affinity cadmium transporter highly expressed in a Thlaspi caerulescens ecotype. New Phytologist, 149, 53-60. http://dx.doi.org/10.1046/j.1469-8137.2001.00003.x

Lòpez -Climent, M. F., Arbona, V., Perez-Clemente, R. M., \& Gomez-Cadenas, A. (2011). Effects of cadmium on gas exchange and phytohormone contents in citrus. Biologia Plantarum, 55, 187-190. http://dx.doi.org/10.1007/s10535-011-0028-4

Mann, S. S., \& Ritchie, G. S. P. (1993). The influence of $\mathrm{pH}$ on on the the forms of cadmium in four west Australian soils. Australian Journal of Soil Research, 31, 255-270. http://dx.doi.org/10.1071/SR9930255

Mensah, E., Odai, S. N., Ofori, E., \& Kyei-Baffour, N. (2008). Influence of transpiration on cadmium (Cd) and lead $(\mathrm{Pb})$ uptake by cabbage, carrots and lettuce from irrigation water in Ghana. Asian Journal of Agricultural Research, 2, 56-60. http://dx.doi.org/10.3923/ajar.2008.56.60

Murray, H., Pinchin, T. A., \& Macfie, S. M. (2011). Compost application affects metal uptake in plants grown in urban garden soils and potential human health risk. Journal of Soils and Sediments, 11, 815-829. http://dx.doi.org/10.1007/s11368-011-0359-y

Nakanishi, H., Ogawa, I., Ishimaru, Y., Mori, S., \& Nishizawa, N. K. (2006). Iron deficiency enhances cadmium uptake and translocation mediated by the $\mathrm{Fe}^{2+}$ transporters OsIRT1 and OsIRT2 in rice. Soil Science and Plant Nutrition, 52, 464-469. http://dx.doi.org/10.1111/j.1747-0765.2006.00055.x

Nriagu, J. O., \& Pacyna, J. M. (1988). Quantitative assessment of worldwide contamination of air, water and soils by trace metals. Nature, 333, 134-139. http://dx.doi.org/10.1038/333134a0

Ogawa, T., Kobayashi, E., Okubo, Y., Suwazono, Y., Kido, T., \& Nogawa, K. (2004). Relationship among prevalence of patients with itai-itai disease, prevalence of abnormal urinary findings, and cadmium concentrations in rice of individual hamlets in the Jinzu river basin, Toyama prefecture of Japan. International Journal of Environmental Health Research, 14, 243-252. http://dx.doi.org/10.1080/09603120410001725586

Peijnenburg, W., Baerselman, R., Groot, A.de, Jager, T., Leenders, D., Posthuma, L., \& Veen, R. V. (2000). Quantification of metal bioavailability for lettuce (Lactuca sativa L.) in field soils. Archives of Environmental Contamination and Toxicology, 39, 420-430. http://dx.doi.org/10.1007/s002440010123

Perfus-Barbeoch, L., Leonhardt, N., Vavasseur, A., \& Forestier, C. (2002). Heavy metal toxicity: cadmium permeates through calcium channels and disturbs the plant water status. The Plant Journal, 32, 539-548. http://dx.doi.org/10.1046/j.1365-313X.2002.01442.x

Salah, S., \& Barrington, S. F. (2006). Effect of soil fertility and transpiration rate on young wheat plants (Triticum aestivum $) \quad \mathrm{Cd} / \mathrm{Zn}$ uptake and yield. Agricultural Water Management, 82, 177-192. http://dx.doi.org/10.1016/j.agwat.2005.06.002

Salt, D. E., Prince, R. C., Pickering, I. J., \& Raskin, I. (1995). Mechanisms of cadmium mobility and accumulation in indian mustard. Plant Physiology, 109, 1427-1433. http://dx.doi.org/10.1104/pp.109.4.1427 
Simmons, R.W., Pongsakul, P., Saiyasitpanich, D., \& Klinphoklap, S. (2005). Elevated levels of cadmium and zinc in paddy soils and elevated levels of cadmium in rice grain downstream of a zinc mineralized area in Thailand: implications for public health. Environmental Geochemistry and Health, 27, 501-511. http://dx.doi.org/10.1007/s10653-005-7857-z

Smolders, E., Oorts, K., Van Sprang, P., Schoeters, I., Janssen, C. R., McGrath, S. P., \& McLaughlin, M.J. (2009). Toxicity of trace metals in soil as affected by soil type and aging after contamination: using calibrated bioavailability models to set ecological soil standards. Environmental Toxicology and Chemistry SETAC, 28(8), 1633-1642. http://dx.doi.org/10.1897/08-592.1

Tanaka, K., Fujimaki, S., Fujiwara, T., Yoneyama, T., \& Hayashi, H. (2007). Quantitative estimation of the contribution of the phloem in cadmium transport to grains in rice plants (Oryza sativa L.). Soil Science and Plant Nutrition, 53, 72-77. http://dx.doi.org/10.1111/j.1747-0765.2007.00116.x

Taylor, G.J., Blamey, F.P.C., \& Edwards, D.G. (1998). Antagonistic and synergistic interactions between aluminum and manganese on growth of Vigna unguiculata at low ionic strength. Physiologia Plantarum, 104, 183-194. http://dx.doi.org/10.1034/j.1399-3054.1998.1040206.x

Ueno, D., Iwashita, T., Zhao, F.J., \& Ma, J.F. (2008). Characterization of Cd translocation and identification of the Cd form in xylem sap of the Cd-hyperaccumulator Arabidopsis halleri. Plant and Cell Physiology, 49, 540-548. http://dx.doi.org/10.1093/pcp/pcn026

United States Environmental Protection Agency. (2005). Test methods for evaluating solid waste, physical/chemical methods, series 3000. [Online] Available: http://www.epa.gov/epaoswer/hazwaste/test/main.htm/ (Jan 4, 2012)

Uraguchi, S., Mori, S., Kuramata, M., Kawasaki, A., Arao, T., \& Ishikawa, S. (2009). Root-to-shoot Cd translocation via the xylem is the major process determining shoot and grain cadmium accumulation in rice. Journal of Experimental Botany, 60, 2677-2688. http://dx.doi.org/10.1093/jxb/erp119

Van der Vliet, L., Peterson, C., \& Hale, B. (2007). Cd accumulation in roots and shoots of durum wheat: the roles of transpiration rate and apoplastic bypass. Journal of Experimental Botany, 58, 2939-2347. http://dx.doi.org/10.1093/jxb/erm119

Vassilev, A., Lidon, F., Matos, M. d. C., Ramalho, J.C., \& Yordanov, I. (2002). Photosynthetic performance and content of some nutrients in cadmium-and copper-treated barley plants. Journal of Plant Nutrition, 25, 2343-2360. http://dx.doi.org/10.1081/PLN-120014699

Wang, G., Su, M.Y., Chen, Y.H., Lin, F.F., Luo, D., \& Gao, S.F. (2006). Transfer characteristics of cadmium and lead from soil to the edible parts of six vegetable species in southeastern China. Environmental Pollution, 144, 127-135. http://dx.doi.org/10.1016/j.envpol.2005.12.023

Zhao, F.J., Hamon, R.E., Lombi, E., McLaughlin, M.J., \& McGrath, S.P. (2002). Characteristics of cadmium uptake in two contrasting ecotypes of the hyperaccumulator Thlaspi caerulescens. Journal of Experimental Botany, 53, 535-543. http://dx.doi.org/10.1093/jexbot/53.368.535

Table 1. Composition of the nutrient solution

\begin{tabular}{cccc}
\hline Macronutrients & Concentration $(\mathrm{mM})$ & Micronutrients & Concentration $(\mu \mathrm{M})$ \\
\hline $\mathrm{Ca}\left(\mathrm{NO}_{3}\right)_{2} \cdot 4 \mathrm{H}_{2} \mathrm{O}$ & 1.0 & $\mathrm{H}_{3} \mathrm{BO}_{3}$ & 6.0 \\
$\mathrm{~K}_{2} \mathrm{HPO}_{4}$ & 1.0 & $\mathrm{MnCl}_{2} \cdot 4 \mathrm{H}_{2} \mathrm{O}$ & 2.0 \\
$\mathrm{KNO}_{3}$ & 0.4 & $\mathrm{ZnSO}_{4} \cdot 7 \mathrm{H}_{2} \mathrm{O}$ & 0.5 \\
$\mathrm{Mg}\left(\mathrm{NO}_{3}\right)_{2} \cdot 6 \mathrm{H}_{2} \mathrm{O}$ & 0.3 & $\mathrm{CuSO}_{4} \cdot 5 \mathrm{H}_{2} \mathrm{O}$ & 0.15 \\
$\mathrm{NH}_{4} \mathrm{NO}_{3}$ & 0.3 & $\mathrm{Na}_{2} \mathrm{MoO}_{4}$ & 0.1 \\
$\mathrm{~K}_{2} \mathrm{SO}_{4}$ & 0.1 & & \\
$\mathrm{FeCl}_{3} \cdot 6 \mathrm{H}_{2} \mathrm{O}$ & 0.01 & & \\
$\mathrm{Na}_{2} \mathrm{EDTA}$ & 0.01 & & \\
\hline
\end{tabular}


Table 2. Dry biomass (SE) of lettuce, barley and radish grown in different $\mathrm{Cd}$ treatments for 28 days

\begin{tabular}{|c|c|c|c|c|c|c|}
\hline Treatments $(\mu \mathrm{M} \mathrm{Cd})$ & \multicolumn{3}{|c|}{ Shoot mass $(\mathrm{g})$} & \multicolumn{3}{|c|}{ Root mass (g) } \\
\hline \multicolumn{7}{|l|}{ Lettuce } \\
\hline 0 & \multicolumn{3}{|c|}{$2.4(0.3) \mathrm{a}$} & \multicolumn{3}{|l|}{$0.6(0.1) \mathrm{a}$} \\
\hline 0.1 & \multicolumn{3}{|c|}{$3.6(0.2) \mathrm{a}$} & \multicolumn{3}{|l|}{$0.9(0.1) \mathrm{a}$} \\
\hline 0.5 & \multicolumn{3}{|c|}{$2.4(0.2) \mathrm{a}$} & \multicolumn{3}{|l|}{$0.7(0.0) \mathrm{a}$} \\
\hline 1.0 & \multicolumn{3}{|c|}{$2.1(0.6) \mathrm{a}$} & \multicolumn{3}{|l|}{$0.5(0.2) \mathrm{ab}$} \\
\hline 2.0 & $1.0(0$. & & & $0.1(0.0) \mathrm{b}$ & & \\
\hline \multicolumn{7}{|l|}{ One-way ANOVA } \\
\hline & $\mathrm{F}_{(4,14)}$ & \multirow{2}{*}{\multicolumn{2}{|c|}{$\begin{array}{l}\mathrm{p} \\
0.003\end{array}$}} & \multirow{2}{*}{$\begin{array}{l}\mathrm{F}_{(4,14)} \\
10.213\end{array}$} & & \\
\hline & 8.567 & & & & 0.001 & \\
\hline \multicolumn{7}{|l|}{ Barley } \\
\hline 0 & \multicolumn{3}{|c|}{$1.8(0.3) \mathrm{a}$} & \multicolumn{3}{|l|}{$0.5(0.1) \mathrm{a}$} \\
\hline 0.1 & \multirow{2}{*}{\multicolumn{3}{|c|}{$1.8(0.1) \mathrm{a}$}} & \multicolumn{3}{|l|}{$0.5(0.0) \mathrm{a}$} \\
\hline 0.5 & & \multirow{2}{*}{\multicolumn{2}{|c|}{$\begin{array}{l}1.1(0.3) \mathrm{b} \\
12(0.2) \mathrm{ab}\end{array}$}} & \multicolumn{3}{|l|}{$0.4(0.1) \mathrm{a}$} \\
\hline 1.0 & $1.2(0$. & & & \multirow{2}{*}{\multicolumn{3}{|c|}{$\begin{array}{l}0.4(0.1) \mathrm{a} \\
0.4(0.1) \mathrm{a}\end{array}$}} \\
\hline 2.0 & \multicolumn{3}{|c|}{$1.0(0.1) \mathrm{b}$} & & & \\
\hline \multicolumn{7}{|l|}{ One-way ANOVA } \\
\hline & $\mathrm{F}_{(4,14)}$ & $\mathrm{p}$ & & $F_{(4,14)}$ & $\mathrm{p}$ & \\
\hline & 3.869 & 0.03 & & 1.153 & 0.387 & \\
\hline & \multicolumn{2}{|c|}{ Shoot mass (g) } & \multicolumn{2}{|c|}{ Lateral root mass $(\mathrm{g})$} & Tap ro & $\operatorname{mass}(\mathrm{g})$ \\
\hline \multicolumn{7}{|l|}{ Radish } \\
\hline 0 & \multicolumn{2}{|c|}{$6.1(1.1) \mathrm{ab}$} & \multicolumn{2}{|l|}{$0.8(0.1) \mathrm{a}$} & $5.2(0$. & \\
\hline 0.05 & \multicolumn{2}{|c|}{$\begin{array}{l}9.4(1.2) \mathrm{a} \\
4.6(0.1) \mathrm{ab}\end{array}$} & \multicolumn{2}{|l|}{$1.0(0.2) \mathrm{a}$} & $2.1(0$. & \\
\hline 0.1 & $4.6(0$. & & $0.6(0.1) \mathrm{a}$ & & $4.5(0$. & \\
\hline 0.2 & $3.4(1$. & & $0.3(0.1) \mathrm{a}$ & & $2.9(0$. & \\
\hline 0.5 & $4.3(1$. & & $0.6(0.3) \mathrm{a}$ & & $3.1(0$. & \\
\hline One-way ANOVA & & & & & & \\
\hline & $\mathrm{F}_{(4,14)}$ & & $F_{(4,14)}$ & $\mathrm{p}$ & $\mathrm{F}_{(4,14)}$ & $\mathrm{p}$ \\
\hline & 5.110 & 017 & 2.041 & 0.164 & 3.257 & 0.059 \\
\hline
\end{tabular}

The results (F statistic and corresponding $\mathrm{p}$ value) of one-way analyses of variance for each tissue type within each species are also shown. Different lower case letters indicate significant differences in dry biomass, as determined by post-hoc tests.

Table 3. Total volume of water transpired (SE) and transpiration per unit leaf area (SE) by lettuce, barley and radish grown in different $\mathrm{Cd}$ treatments

\begin{tabular}{cccccccc}
\hline \multirow{2}{*}{$\begin{array}{c}\text { Treatme } \\
\mathrm{nt}\end{array}$} & $\begin{array}{c}\text { Volume } \\
(\mathrm{ml})\end{array}$ & $\begin{array}{c}\text { Transpiration } \\
\left(\mathrm{ml} / \mathrm{cm}^{2}\right)\end{array}$ & $\begin{array}{c}\text { Volume } \\
(\mathrm{ml})\end{array}$ & $\begin{array}{c}\text { Transpiration } \\
\left(\mathrm{ml} / \mathrm{cm}^{2}\right)\end{array}$ & $\begin{array}{c}\text { Treatment } \\
(\mu \mathrm{M} \mathrm{Cd})\end{array}$ & Volume $(\mathrm{ml})$ & $\begin{array}{c}\text { Transpiration } \\
\left(\mathrm{ml} / \mathrm{cm}^{2}\right)\end{array}$ \\
\hline 0 & $788(94) \mathrm{a}$ & $0.64(0.05) \mathrm{c}$ & $1095(44) \mathrm{a}$ & $1.74(0.18) \mathrm{a}$ & 0 & $3088(19) \mathrm{a}$ & $2.18(0.44) \mathrm{ab}$ \\
0.1 & $957(38) \mathrm{a}$ & $0.51(0.05) \mathrm{c}$ & $1047(12) \mathrm{a}$ & $1.65(0.06) \mathrm{a}$ & 0.05 & $3138(356) \mathrm{a}$ & $1.34(0.02) \mathrm{b}$ \\
0.5 & $731(52) \mathrm{a}$ & $0.59(0.03) \mathrm{c}$ & $683(93) \mathrm{b}$ & $2.02(0.40) \mathrm{a}$ & 0.1 & $2661(156) \mathrm{ab}$ & $2.3(0.14) \mathrm{ab}$ \\
1.0 & $758(98) \mathrm{a}$ & $0.88(0.04) \mathrm{b}$ & $730(67) \mathrm{b}$ & $2.02(0.09) \mathrm{a}$ & 0.2 & $2187(173) \mathrm{b}$ & $2.1(0.14) \mathrm{ab}$ \\
2.0 & $528(54) \mathrm{b}$ & $1.12(0.05) \mathrm{a}$ & $698(32) \mathrm{b}$ & $2.10(0.28) \mathrm{a}$ & 0.5 & $1971(32) \mathrm{b}$ & $2.5(0.06) \mathrm{a}$ \\
\hline $\mathrm{F}_{(4,14)}$ & 4.529 & 31.875 & 12.601 & 0.728 & & 7.517 & 4.066 \\
$\mathrm{p}$ & 0.024 & 0.001 & 0.001 & 0.59 & & 0.005 & 0.033 \\
\hline
\end{tabular}

The results of one-way analyses of variance (F statistic and corresponding $\mathrm{p}$ value) for each variable within each species are also shown. Different lower case letters indicate significant differences in transpiration per unit leaf area and total volume of water transpired, as determined by post-hoc Tukey tests. 
Table 4. Shoot $\mathrm{Cd}$ as a percentage of total $\mathrm{Cd}(\mathrm{SE})$ in lettuce, barley and radish

\begin{tabular}{|c|c|c|}
\hline Species & \multicolumn{2}{|c|}{ Proportion of total $\mathrm{Cd}$ in the shoot (\%) } \\
\hline Lettuce & \multicolumn{2}{|c|}{$84.47(1.65) \mathrm{a}$} \\
\hline Barley & \multicolumn{2}{|c|}{$21.26(1.32) \mathrm{c}$} \\
\hline Radish & \multicolumn{2}{|c|}{$66.15(2.97) \mathrm{b}$} \\
\hline \multicolumn{3}{|c|}{ One-way ANOVA } \\
\hline & $\begin{array}{c}\mathrm{F}_{(2,35)} \\
296.405\end{array}$ & $\begin{array}{c}\mathrm{p} \\
0.001\end{array}$ \\
\hline
\end{tabular}

Data from each Cd treatment (0.1-2.0 $\quad \mathrm{M} \mathrm{Cd}$ for lettuce and barley, and 0.05-0.5 $\mathrm{M}$ Cd from radish) were pooled ( $\mathrm{n}=12$ for each mean value) prior to the calculation of the proportion of total $\mathrm{Cd}$ that accumulated in the shoot. The results of the one-way analysis of variance ( $F$ statistic and corresponding $p$ value) are also shown. Different lower case letters indicate significance differences in $\mathrm{Cd}$ translocation, as determined by post-hoc Tukey tests.

\section{Cd concentration}
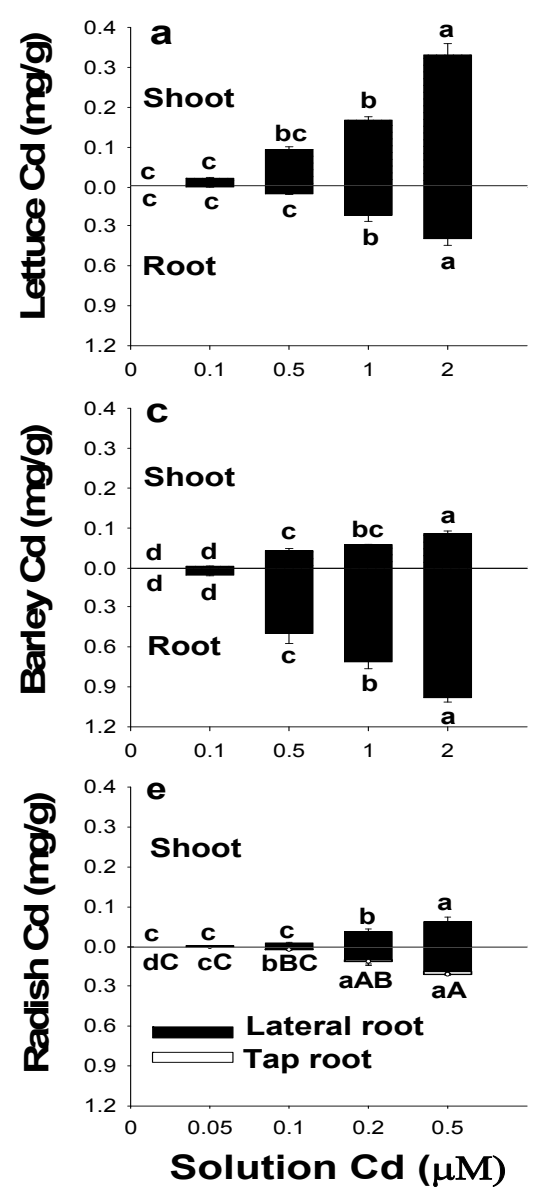

\section{Cd accumulation}
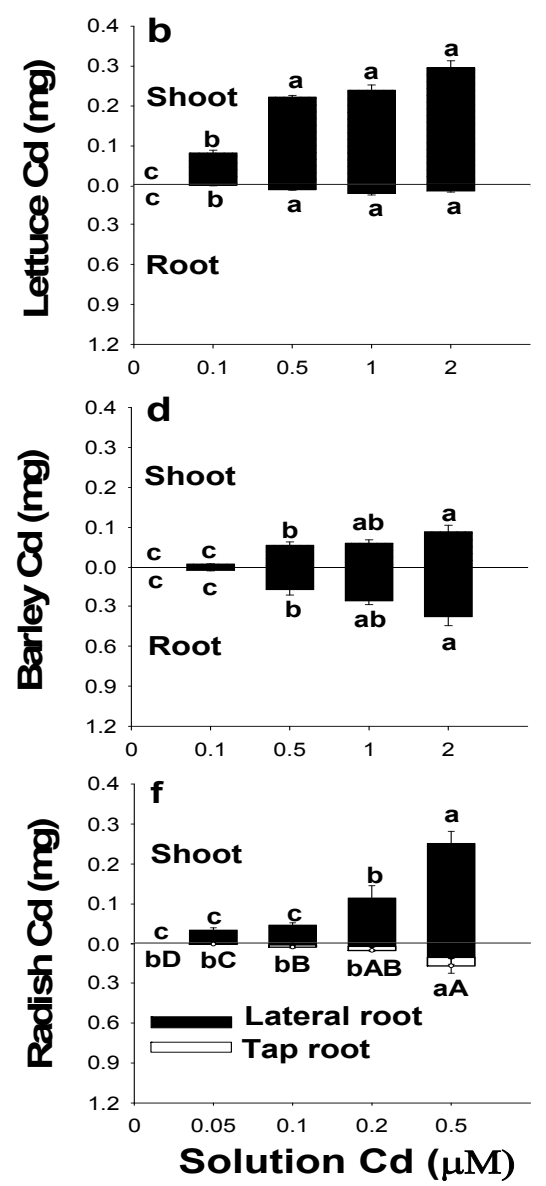

Figure 1. Accumulation of $\mathrm{Cd}$ in lettuce, barley and radish grown in different $\mathrm{Cd}$ treatments for 28 days

Concentrations of $\mathrm{Cd}$ (left-side panels) and total amounts of $\mathrm{Cd}$ (right-side panels) are shown for shoots and roots of $(\mathrm{a}, \mathrm{b})$ lettuce, $(\mathrm{c}, \mathrm{d})$ barley and $(\mathrm{e}, \mathrm{f})$ radish. Within each species, different lower case letters indicate significance differences in $\mathrm{Cd}$ concentration and $\mathrm{Cd}$ accumulation for shoots and roots, as determined by post-hoc Tukey tests. For radish, differences between lateral roots are indicated by lower case letters, and differences between tap roots are indicated by upper case letters. 

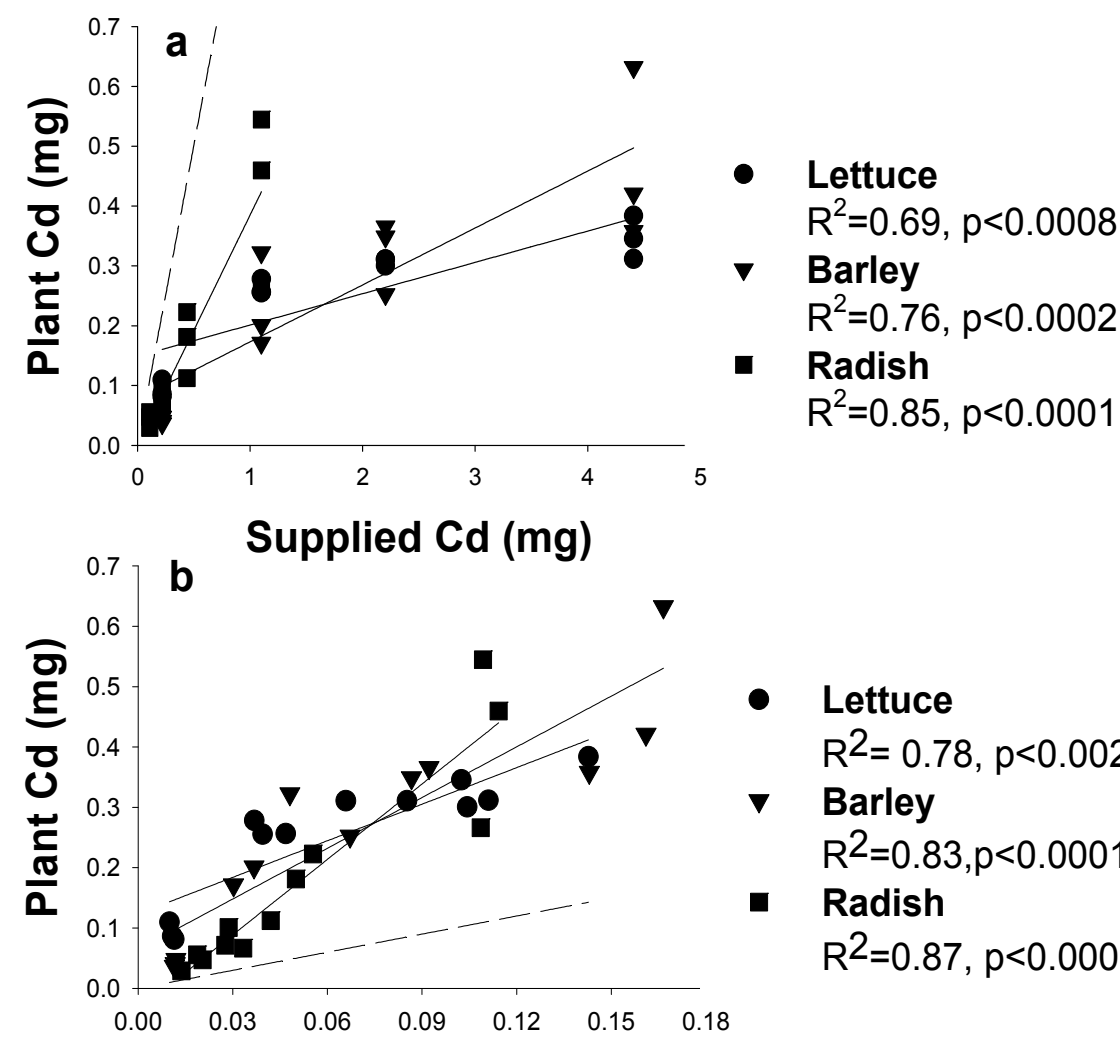

- Lettuce

$R^{2}=0.78, p<0.002$

v Barley $R^{2}=0.83, p<0.0001$

- Radish

$R^{2}=0.87, p<0.0001$

Transpiration Cd (mg)

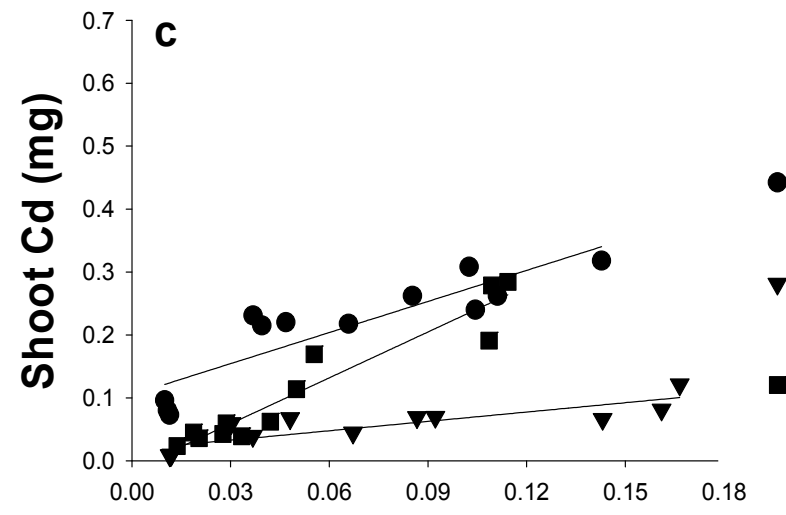

- Lettuce

$$
R^{2}=0.78, p<0.0001
$$

v Barley $\mathrm{R}^{2}=0.73, \mathrm{p}<0.0004$

- Radish $R^{2}=0.91, p<0.0001$

Transpiration Cd (mg)

Figure 2. Relationships between $\mathrm{Cd}$ accumulation and $\mathrm{Cd}$ supply in lettuce, barley and radish

(a) The total amount of $\mathrm{Cd}$ in each plant is plotted against the total amount of Cd supplied in the growth medium. The dashed line illustrates the maximum amount of $\mathrm{Cd}$ that could have been taken up by the plants. (b) The total amount of $\mathrm{Cd}$ in each plant is plotted against the amount of $\mathrm{Cd}$ in the volume of water that was taken up by each plant. The dashed line represents the maximum $\mathrm{Cd}$ available through transpiration. (c) The total amount of $\mathrm{Cd}$ in the shoot of each plant is plotted against the amount of $\mathrm{Cd}$ in the volume of water that was taken up by each plant. Circles, triangles and squares illustrate lettuce, barley and radish, respectively. The solid lines represent lines of best fit for each plant species. 


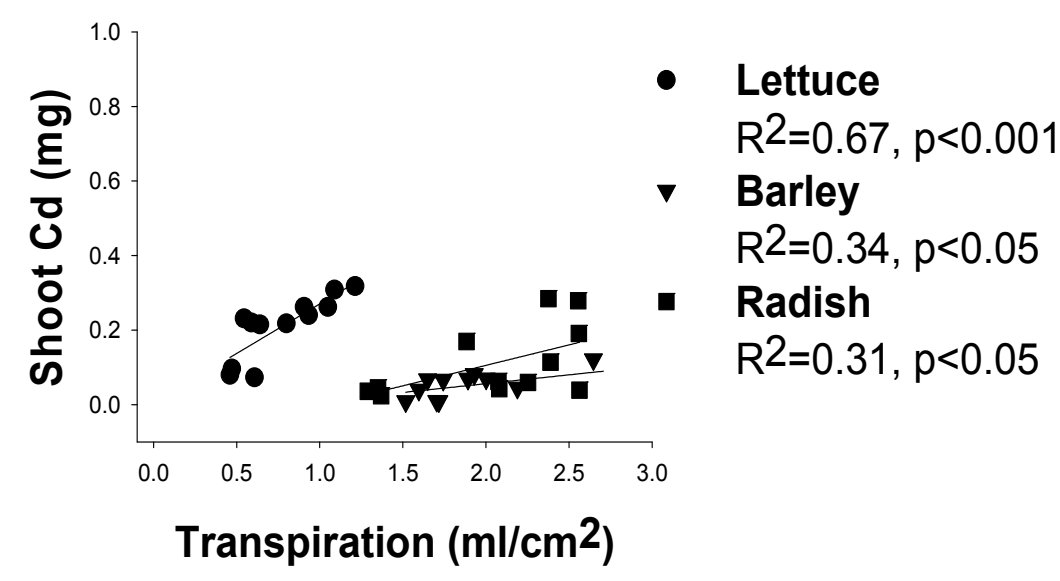

Figure 3. Relationship between $\mathrm{Cd}$ translocation and transpiration in lettuce, barley and radish

The total amount of $\mathrm{Cd}$ in the shoot of each plant is plotted against transpiration per unit leaf area. Circles, triangles and squares illustrate lettuce, barley and radish, respectively. The solid lines represent lines of best fit for each plant species. 